\title{
Impact of Abattoir Wastes on Groundwater Quality in the Fet, Abuja-Nigeria: A Case Study of Gwagwalada Satellite Town
}

\author{
Ekpetere O. Kenneth $^{1^{*}} \quad$ Ekeh O. Faith $^{2^{*}}$ Ofodum N. Modestus ${ }^{3}$ \\ 1.Department of Geography and Environmental Management, University of Abuja, PMB117, Abuja, Nigeria \\ 2.Department of Botany, Faculty of Biological Sciences, Nnamdi Azikiwe University Nigeria \\ 3.Department of Pure and Industrial Chemistry, Chukwuemeka Odumegwu Ojukwu University, P.M.B 02 Uli \\ Anambra State, Nigeria
}

\begin{abstract}
The research examined the impact of abattoir wastes on Groundwater quality in the FCT, Abuja-Nigeria, with Gwagwalada satellite town as a case study. Water samples were collected from three points including wells and boreholes in the study area. The water samples were tested for selected physical, chemical and biological parameters such as Total Dissolved Solid, Total Suspended Solid, Biological oxygen demanded, pH, nitrate, turbidity and total coliform. The laboratory analyses were carried out using standard analytical methods and procedures for water quality analysis. The results shows that ground water near slaughter houses poses environmental and health risk to the users if not treated as the parameters examined shows the lowering of the water quality and making the groundwater unhealthy for drinking and other uses. The study recommends creating awareness and treating of underground water in slaughter areas before use.
\end{abstract}

Keywords: Slaughterhouse, abattoir, ground water, water samples, chemical parameters, environment, health, risk, hygiene, effluent, incineration, contamination, control points.

DOI: $10.7176 / \mathrm{JEES} / 9-4-12$

Publication date: April $30^{\text {th }} 2019$

\section{INTRODUCTION}

Abattoir, also known as slaughterhouse; has been defined as a premises approved and registered by the controlling authority for hygienic slaughtering and inspection of animals, processing, effective preservation and storage of meat produced for human consumption (Omole, 2008). While slaughtering these animals results in significant meat supply, a good source of protein and production of useful by-product such as leather, skin and bones, the processing activities involved sometimes results in environmental pollution and other health challenges that may threaten animal and human health (Ogboru, 2001). The US Environmental Protection Agency (1999) defined meat hygiene as a system of principle designed to ensure that meat product is safe, wholesome and processed in a hygienic manner and are fit for human consumption.

Previous studies have shown that the characteristics of abattoir wastes and effluents vary from day to day depending on the number of stocks being processed (Tebut, 1983). These wastes from abattoir operation can also be separated into solid, liquid and fat. The wastes are highly organic. The solid waste includes condensed meat, undigested feed, bones, horns, hair, and aborted fetus. The liquid waste is usually composed of dissolved solids, blood, gut content, urine, and water; while the fatty waste consists of fat oil, grease which are characterized with high organic levels (Magaji, 2000). Animal waste is usually microbiologically contaminated by micro-organism living naturally or entering it from the surrounding such as those resulting from processing operations. The killing of animals for community consumption is inevitable in most nations of the world and dated back to antiquity which result in in the pollution of the underground aquifer (Chukwu, 2008). Environmental problems are not new. Human societies have long had a major impact on environmental or natural resources. Their tendency to exploit it as if it were inexhaustible resources has repeatedly led to disaster, sometimes leading to the loss of entire human communities. Man in every corner of the world is thus making demands upon his surrounding and thereby altering his own natural environment and that of other living organisms.

In Nigeria, Maduka (2005) reported that cow brought for slaughtering produce $67.8 \mathrm{Kg}$ of waste in dung, bone, blood, horn, and hoof. Foster (2005) submitted that the disposal of waste product is a problem that has always dominated the slaughtering sector an average of 45 percent of the waste consist of non-meat substance. The characteristic of slaughter waste and effluent vary from day to day and it depends on the number of animals, the type of animals, the kind of stock that is being processed and the methods by which these animals are being killed in the abattoir. However, Meadows (1995) reported that waste can affect water, land and air quality, he also reported that abattoir effluent reaching streams and underground water contributes significant levels of nitrogen, phosphorus, biochemical oxygen demanded and other nutrient resulting in stream pollution. Medical experts were reported to have associated some diseases with abattoir activities which include pneumonia, diarrhea, typhoid fever, asthma, wool sorter disease. The pollution load on a water body from abattoir effluent can be quite high. For example, studies did in Canada and Nigeria show very high contaminant levels in abattoir effluent (Turk, 1980). Most of these are known to be hazardous to human beings and aquatic life. Likewise 
improper disposal of effluent from slaughterhouse could lead to transmission of the pathogen to humans and cause diseases such as bacillus salmonella infection, brucellosis, and helminths disease and infection. It is reported that in developed countries an estimated 80 percent of all diseases and over one-third of death are caused by consuming contaminated water (UNESCO, 2006).

The abattoir in Gwagwalada and many others in Nigeria has been facing poor management and this carelessness has led to the loss of lives of the people who live in the abattoir vicinity and to all who consume the meats from these abattoirs (Magaji, 2009). The poor state of the Gwagwalada abattoir and the resultant risk of consuming unwholesome meat and polluted groundwater has become an issue of public health in Gwagwalada. It is as a result of this foregoing that this study is investigating the assessment of the effects of abattoir effluence on groundwater quality in Gwagwalada Abuja.

\section{RESEARCH AIM AND OBJECTIVES}

The aim of this research is to assess the Impact of abattoir effluents on the groundwater quality in Gwagwalada. The study pursued the following objectives;

- Identify the different types of waste generated from the abattoir and the disposal method employed.

- Identify the biological, physical and chemical concentration of groundwater within and around the abattoir.

- Compare the concentration of the groundwater with the World Health Organization (WHO) standard for drinking water.

- Determine the possible impact of any pollutant found in the water on human health, animal and the environment.

\section{THE STUDY AREA}

The study area is Gwagwalada town. Gwagwalada town is one of the largest satellite towns and the third largest urban center in the Federal Capital Territory (NPC, 1991). It is one of the most densely populated areas in the federal capital territory (FCT) and the headquarters of one of the oldest councils in the Federal Capital Territory, Abuja (Ejaro, 2013). Nigeria new Federal Capital Territory was established in 1991, all federal establishments were meant to relocate their corporate headquarters to Abuja. The city witnessed a tremendous influx of civil servants and the organized private sector bringing about an explosion of the population into and around the federal capital city (FCC). As a result, Gwagwalada also witnessed remarkable expansion and increased land conversion rate leading to temperature increase over time. The gradual loss of vegetal cover for construction and subsequent buildings and urbanization generally led to a temperature increase in Gwagwalada town with time (Ejaro, 2013). Gwagwalada town is located about 55 kilometers away from the Federal Capital City (FCC) within the Federal Capital Territory. It lies between latitude $08^{\circ} 55^{\prime} \mathrm{N}$ and $09^{\circ} 00^{\prime} \mathrm{N}$ and longitude $07^{\circ} 00^{\prime} \mathrm{E}$ and $07^{0} 05 \mathrm{E}$ (Balogun, 2001). Gwagwalada township region has a total land mass of about 6,500 hectares.

Gwagwalada town consists of the older traditional and new planned sections. The old is the pre-1976 section, while the latter results from the development of the Federal Capital Development Authority in accordance with its planned role in the spatial development of the Federal Capital Territory (FCT). Its two parts internal structure is quite similar to the pre-colonial urban centers in western and northern parts of Nigeria (Balogun, 2001). The urban or planned areas are places in Gwagwalada, where the development of the town is intended to spread out from hence acting as growth pole of Gwagwalada town such places are phase1,2, and 3, (FCDA, 2000). 


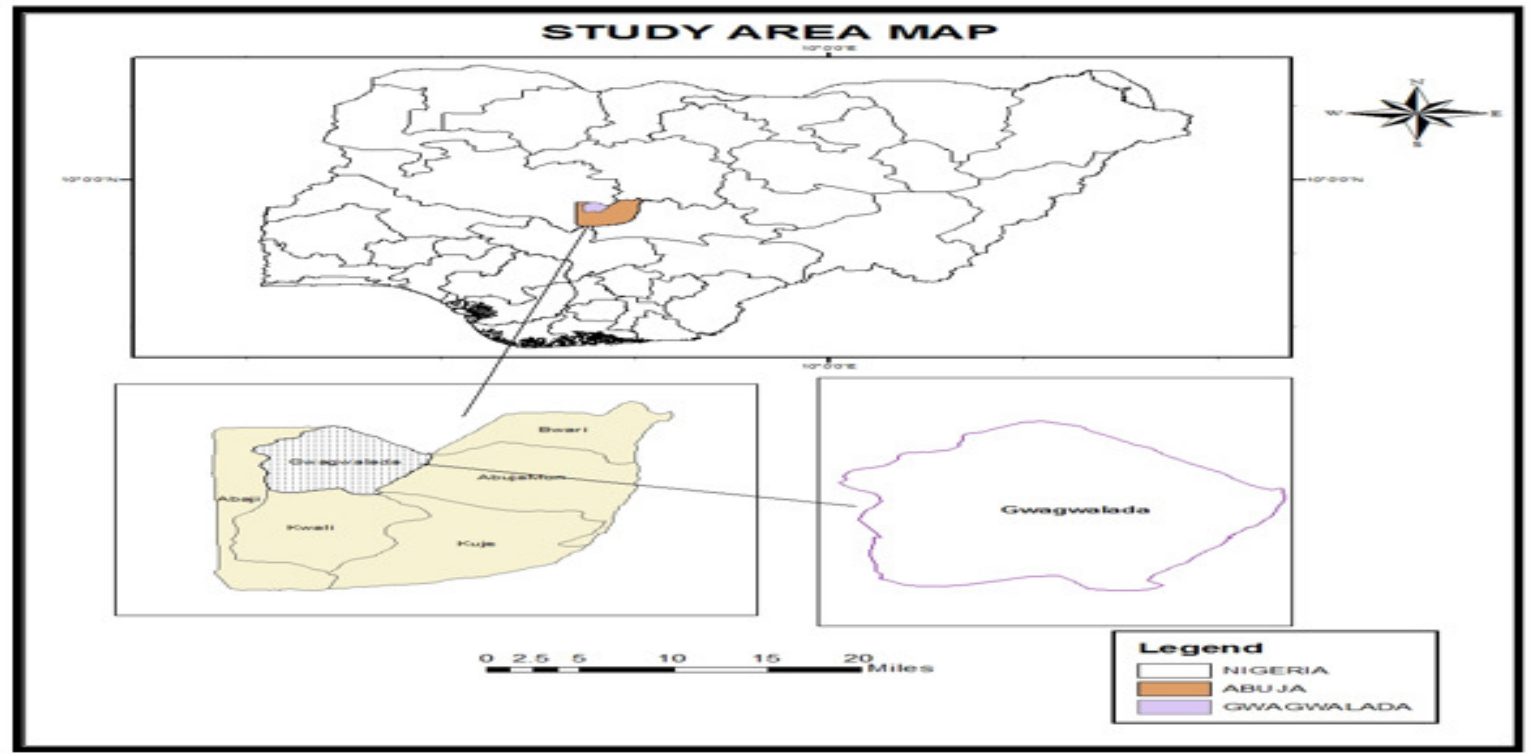

Fig.1: Map of the Study Area

Source: Department of Land use Administration, Gwagwalada Area Council (2018)

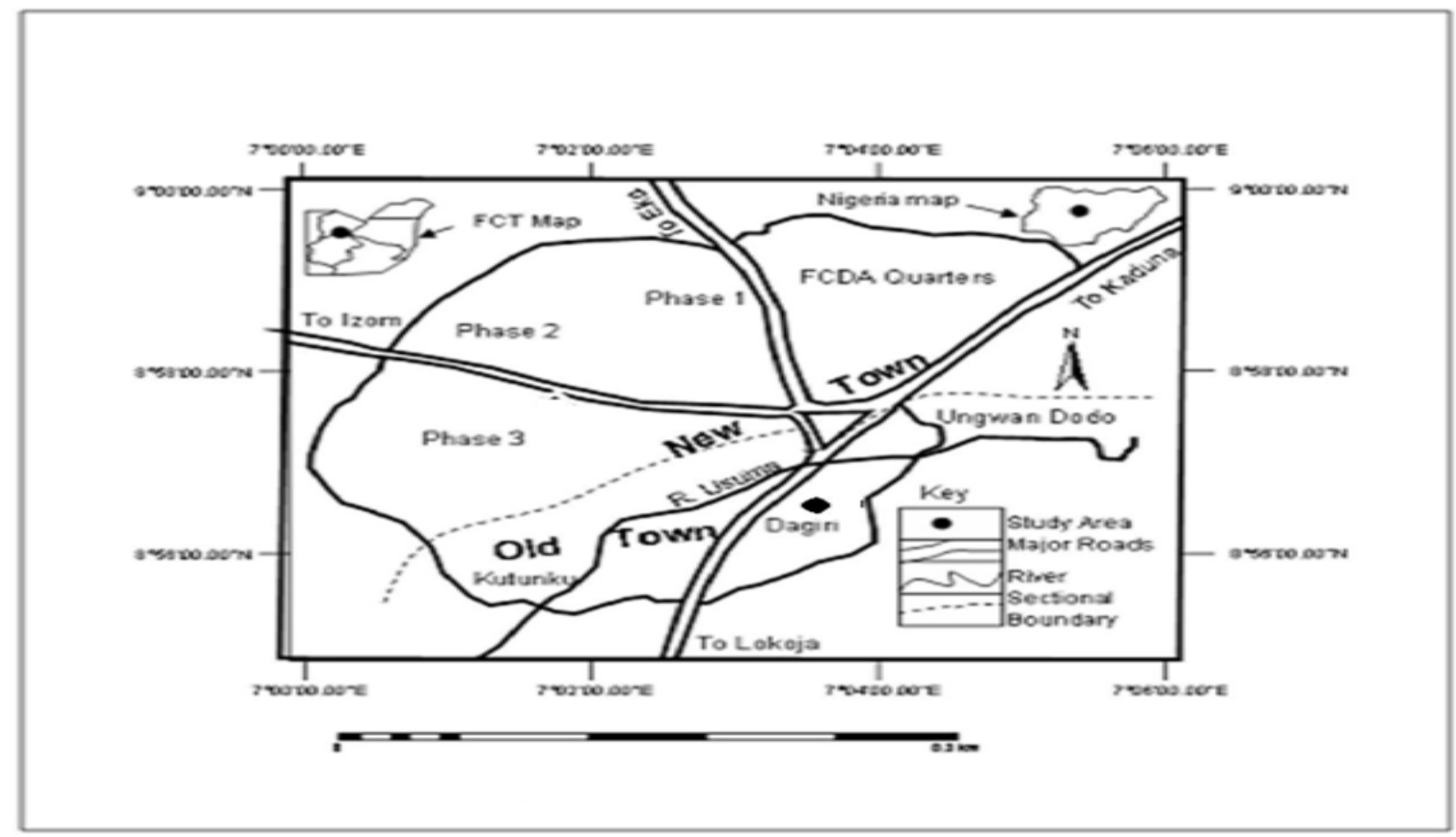

Fig. 2: Map of Gwagwalada Town

Source: Department of Land use Administration, Gwagwalada Area Council (2018)

\section{LITERATURE REVIEW}

\subsection{Water Chemistry and Quality}

The importance of groundwater quality has become increasingly recognized as the development of groundwater continues to expand in British Columbia. Monitoring of groundwater quality is becoming more important because of contamination concerns and development of new equipment and techniques for measuring contaminants in minute concentrations (Alonge, 1991). Although groundwater is generally less susceptible to contamination than surface waters it is usually more highly mineralized in its natural state. As water moves slowly through the ground it can remain for extended periods of time in contact with minerals present in the soil and bedrock and become saturated with dissolved solids from these minerals. This dissolution process continues until chemical equilibrium is reached between the water and the minerals with which it is in contact (Adelegan, 
2002). The types and relative concentrations of the chemical constituents in ground water provide information on the evolution of ground waters, age (residence time), and solubility, rates of movement, flow history and sources of recharge. Older ground waters, for example, are generally more mineralized than younger ground waters (Bello, 2009). Fresher ground waters are normally associated with recharge areas whereas ground waters in discharge areas are more mineralized. Groundwaters can be classified according to the most dominant percentage of cations and anions being present based on concentrations in equivalents per million [epm] (e.g. calcium-magnesium bicarbonate type) (Foster, 2005).

\subsubsection{Mineral Constituents}

The greater part of the soluble constituents in groundwater comes from soluble minerals in soils and sedimentary rocks. The more common soluble constituents include calcium, sodium, bicarbonate and sulphate ions (Kelvin, 2000). Another common constituent is chloride ion derived from intruded sea water, connate water, evapotranspiration concentrating salts, and sewage wastes for example. Nitrate can be a natural constituent but high concentrations often suggest often cause pollution (WHO, 2004)

\subsubsection{Quality Characteristics}

The measure of Total Dissolved Solids (TDS) is a good indicator of the mineralized character of the water. Groundwater having less than $500 \mathrm{mg} / \mathrm{L}$ of total dissolved solids is generally satisfactory for domestic and industrial use while groundwater having greater than $1000 \mathrm{mg} / \mathrm{L}$ of total dissolved solids is generally unsatisfactory for these uses. High total dissolved solids are often indicative of other characteristics such as hardness (Okecha, 2000). Other properties that are especially useful in determining groundwater character are hardness, specific conductance and $\mathrm{pH}$ these constituents can be determined by simple procedures using field equipment (Dikka, 2011). In order to more precisely identify and measure the quality characteristics of groundwater, chemical, physical and biological analysis are usually required. Chemical analysis requires the laboratory determination of the concentrations of common ions found in groundwater and is commonly reported in units of milligrams per liter $(\mathrm{mg} / \mathrm{L})$ (Longe, 2008). Concentrations may also be expressed as equivalents per million (epm) which is the moles of solute multiplied by the valence of the solute species in 10,000,000 $\mathrm{g}$ of water. Properties of groundwater often evaluated in a physical analysis include temperature, turbidity, odour, taste, and colour (Abattoir, 1988). The biological analysis includes a coliform bacteria test which indicates the sanitary quality of the water for human consumption. Additional parameters may be tested if a more detailed analysis is requested or where known or suspected sources of pollution exist. Some substances even in small concentrations can be troublesome (Ogboru, 2001). For example, iron concentrations of 1 to $5 \mathrm{mg} / \mathrm{L}$ in groundwater are common throughout British Columbia and can cause staining to plumbing fixtures and laundry, encrust well screens and clog pipes. Manganese in small concentrations can also cause staining and is even more objectionable as stains are harder to remove than those caused by iron (Okecha, 2000).

Chloride contamination is possible in wells located near the sea where pumping of these wells can move seawater into the freshwater aquifer making water not portable. Groundwater containing dissolved hydrogen sulphide gas is another common problem which imparts a characteristic "rotten egg" odour and taste to the water (Magaji, 2009). Hydrogen sulphide will combine with other impurities in the water to form iron sulphide (black water), calcium sulphide, and sodium sulphide. While TDS, specific conductance, hardness, and $\mathrm{pH}$ are good indicators of the character of groundwater, tritium $(3 \mathrm{H})$ and carbon $14(14 \mathrm{C})$ which are radioactive isotopes are good indicators of the age of groundwater. Between 1952 and 1962 large scale atmospheric testing of thermonuclear bombs were carried out and atmospheric contamination occurred. It is therefore apparent that groundwater from a location in the northern hemisphere, containing tritium at levels of hundreds or thousands of TU (tritium units), entered the groundwater zone after 1953 (Magaji, 2009). If the water has less than 5-10 TU it must have entered the groundwater zone prior to 1953. Two non-radioactive isotopes which occur in water are oxygen $18(180)$ and deuterium $(2 \mathrm{H})$ and serve mainly as indicators of groundwater source areas and as evaporation indicators in surface water bodies (Osinbanjo, 2007).

\subsection{Groundwater Pollution}

Groundwater pollution (also called groundwater contamination) occurs when pollutants (effluents) are released to the ground and make their way down into groundwater. It can also occur naturally due to the presence of a minor and unwanted constituent, contaminant or impurity in the groundwater, in which in some cases it is more likely referred to as contamination rather than pollution. The pollutant creates a contaminant plume within an aquifer (Bello, 2009). Movement of water and dispersion within the aquifer spreads the pollutant over a wider area. Its advancing boundary, often called a plume edge, can intersect with groundwater wells into surface water such as seeps and spring, making the water supplies unsafe for humans and wildlife. The movement of the plume, called a plume front, may be analyzed through a hydrological transport model or groundwater models. Analysis of groundwater pollution may focus on soil characteristics and site geology, hydrogeology, hydrology, and the nature of the contaminants (Kelvin, 2000).

Pollution can occur from on-site sanitation systems, landfills, effluent from wastewater treatment plants, 
leaking sewers, petrol stations or from over application of fertilizers in agriculture. Pollution (or contamination) can also occur from naturally occurring contaminants, such as fluoride. Using polluted groundwater causes hazards to public health through poisoning or the spread of disease (Longe, 2008). Different mechanisms have an influence on the transport of pollutants, e.g. diffusion, absorption, precipitation, decay, in the groundwater. The interaction of groundwater contamination with surface waters is analyzed by use of hydrology transport models (Tebutt, 1983).

\subsection{Types of Groundwater Pollutants}

Contaminants found in groundwater cover a broad range of physical, inorganic chemical, organic chemical, bacteriological, and radioactive parameters. Principally, many of the same pollutants that play a role in surface water pollution may also be found in polluted groundwater, although their respective importance may differ (USEPA, 1980).

\subsubsection{Pathogen}

Waterborne diseases can be spread via a groundwater well which is contaminated with faecal pathogens from pit latrines Pathogens contained in human or animal faeces can lead to groundwater pollution when they are given the opportunity to reach the groundwater, making it unsafe for drinking of the four pathogen types that are present in faeces (bacteria, viruses, protozoa, and helminths or helminth eggs), the first three can be commonly found in polluted groundwater, whereas the relatively large helminth eggs are usually filtered out by the soil matrix (UNESCO, 2006).

Groundwater that is contaminated with pathogens can lead to fatal focal-oral transmission of diseases (e.g. cholera, diarrhoea). If the local hydrogeological conditions (which can vary within a space of a few square kilometres) are ignored, pit latrines can cause significant public health risks via contaminated groundwater (Robert, 2005).

\subsubsection{Nitrate}

In addition to the issue of pathogens, there is also the issue of nitrate pollution in groundwater from pit latrines, which has led to numerous cases of "blue baby syndromes" in children, notably in rural countries such as Romania and Bulgaria. Nitrate levels above $10 \mathrm{mg} / \mathrm{L}(10 \mathrm{ppm})$ in groundwater can cause "blue baby syndrome" (acquired methemoglobinemia) (Maduka, 2005). Nitrate can also enter the groundwater via excessive use of fertilizers, including manure. This is because only a fraction of the nitrogen-based fertilizers is converted to produce and other plant matter. The remainder accumulates in the soil or lost as run-off. High application rates of nitrogen-containing fertilizers combined with the high water-solubility of nitrate leads to increased runoff into surface water as well as leaching into groundwater, thereby causing groundwater pollution (Magaji, 2009). The excessive use of nitrogen-containing fertilizers (be they synthetic or natural) is particularly damaging, as much of the nitrogen that is not taken up by plants is transformed into nitrate which is easily leached. The nutrients, especially nitrates, in fertilizers can cause problems for natural habitats and for human health if they are washed off soil into watercourses or leached through soil into groundwater (Magaji, 2009).

4.3.3 Volatile organic compounds

Volatile organic compounds (VOCs) are a dangerous contaminant of groundwater. They are generally introduced to the environment through careless industrial practices. Many of these compounds were not known to be harmful until the late 1960 s and it was some time before regular testing of groundwater identified these substances in drinking water sources (Magaji, 2009).

\subsection{Sources of Waste in Red Meat Abattoir}

The different sources of waste in red meat abattoir could be categorised as animal pens, bleeding, carcass processing, Offal and by-product processes and processing. A cow brought for slaughtering produced $67.8 \mathrm{~kg}$ of waste in form of dung, blood, horn and hoof (Meadows, 1995). The disposal of waste product is a problem that has always dominated by slaughter sector and average 45 per cent of each live animal 53 per cent of each sheep and 3.4 per cent of each pig consist of non-meat substance (Robert 2005). The characteristics of abattoir waste and effluents vary from day to day depending on the number, type of stock being processed and this waste could be highly organic with relative high level of suspend solid liquid and gas.

\subsection{Types of Abattoir Waste}

Abattoir waste can commonly be classified into three namely solid waste, liquid waste and gaseous waste.

- Solid waste

The processing of meat material is the beginning of the solid waste generation. Solid waste is classified as garbage and rubbish. Garbage is putrefied waste from food processing industries while rubbish is a nonperishable waste that is either combustible or non-combustible such as paper, carton, and wood. Abattoir solid wastes are made of carcasses, bones, scraps of inedible tissue, horns, hooves, feather (American Public Health Association (APHA) 1995.)These solid wastes can as well contaminate the groundwater (Meadows 1995). This 
leach consists largely of solid microbial organisms and in some situations, chemicals and shallow wells more dangerously polluted (Meadows 1995).

- Liquid waste

Abattoir liquid waste usually composed of dissolved solids, blood; gut content, urine and fat, waste water, the waste still consist of fat/oil. The meat processing industries generate large quantities of effluents rich in organic compounds and nutrient and also require the tools available to manage waste water effectively. Waste water may be defined as the combination of liquid or waste water removed from residuals, institutions, commercial and industrial centers (Chukwu, 2008).

- Gaseous waste

Gaseous waste includes mal-odorous gases which results from putrefaction of carcass, decomposition of organic materials, and the smoke from burning of hides of these animals lead to the pollution of the atmosphere as well. If untreated waste water is allowed to accumulate, the decomposition of organic materials it contains can lead to the production of large quantities of mal-odorous gases. Sometimes great and uncontrollable odour comes from the heap of animal dungs in the abattoir; odour can as well come from the decay and decomposition of some of these effluents in the abattoir. Greenhouse gas emission and pollution are two serious environmental side effects of abattoirs, abattoir effluents adversely impacts human health, agriculture, potable water and ecology of aquatic species, this has become a major problem for many urban communities in Nigeria.

\subsection{Methods of Disposal and treatment of Abattoir wastes}

Waste disposal is a major issue for abattoir projects. There are two main component of waste disposal, including, one for the solid materials and one for liquids. The constraints relating to both have become more significant in recent times due to issue such as BSE (Bovine Spongiform Encephalopathy, also known as mad cow disease), water pollution, landfill restrictions and rendering industry charges (BCFPA, 2005).The British Colombia Food Processors Association (BCFPA) 2005 has identified the following as methods that can be employed in the disposal of abattoir wastes.

- Composting

This is the controlled biological decomposition of organic solid waste under aerobic conditions that result in humus-like compost or compost-like material. Compost therefore can be said to be the aerobically decomposed remnant of organic matter. The standard method for condemned meat composting is done by bedding the meat on a layer of carbonaceous material and then covering it with chicken manure in alternate layers in a bin and covered with a layer of compost which acts as an insulator and smell inhibitor. The compost is turned every six weeks and the process usually takes around 6-12 weeks to completely breakdown the meat and renders it to compost- like product (BCFPA, 2005).

- Incineration

This is the controlled burning of abattoir solid waste at over $1000^{\circ} \mathrm{c}$ for several hours. The aim of doing this is to sterilize and reduce the quantity of waste. This method however requires substantial capital and operating costs (BCFPA, 2005).

- Burial

This method is used for dead stock and other meat production waste by producers, abattoirs and dead stock collectors. The requirement for burial is that the dead stock or condemned meat must be covered with at least 2 feet of earth (BCFPA, 2005).

\section{- Rendering}

This is a process which is applied to materials derived from slaughters, packing, processing, food preparation and dead stock, involving cooking, removing the moisture and separating the materials into sterile animal protein meal and fat products such as tallow, meat and bone meal (MBM), meat meal, blood and feather meal. The muscle, fat, bones and other animal tissues are changed into a protein substance which looks like sand or soil- a much safer, more easily stored and less objectionable form. Unlike raw waste materials, the products derived from rending can be stored for a long period of time. The temperature and length of the rendering process kill or initiates traditional disease-causing organisms. Rendering thus recycles what would otherwise have been substantial amounts of waste. The rendering plant products can be used as animal feed additives; they are also used in oil lamps, candles and in the manufacture of soap and biofuels (BCFPA, 2005). These methods, however, have their merits and demerits. 
Table 1 Advantage and Disadvantages of Waste Disposal Options

\begin{tabular}{|l|l|l|}
\hline $\begin{array}{l}\text { Disposal } \\
\text { Method }\end{array}$ & Advantages & Disadvantages \\
\hline Burial & $\begin{array}{l}\text { Inexpensive if suitable land is } \\
\text { available }\end{array}$ & $\begin{array}{l}\text {-Risk of disease transmission and pollution } \\
\text {-It does not destroy prison and pathogens } \\
\text {-It requires substantial land and earth moving equipment } \\
\text { for larger animals. }\end{array}$ \\
\hline Composting & $\begin{array}{l}\text {-It may destroy some pathogens } \\
\text { (partial sterilization). } \\
\text {-It is usually cheaper than } \\
\text { rendering or incineration }\end{array}$ & $\begin{array}{l}\text {-Risk of disease transmission and pollution } \\
\text {-It does not destroy prions and pathogens } \\
\text {-It requires significant land, earth moving equipment and } \\
\text { material high in carbon eg Saw dust wood clips } \\
\text {-It may reduce the value of land }\end{array}$ \\
\hline Incineration & $\begin{array}{l}\text {-It destroys most pathogens } \\
\text {-Significantly reduces volume } \\
\text {-It can recycle waste }\end{array}$ & $\begin{array}{l}\text {-Not all pathogens are destroyed e.g (BSE) } \\
\text {-It is costly unless cost is covered by income form products } \\
\text {-It requires the collection and storage of wastes. }\end{array}$ \\
& $\begin{array}{l}\text { ( sterilize the waste) } \\
\text {-At high temperature }\left(1000^{\circ} \mathrm{C}\right) \\
\text { inactivates prions }\end{array}$ & $\begin{array}{l}\text {-If not done properly may pollute the air. } \\
\text {-The equipment, operation, and maintenance of incinerators } \\
\text { are expensive }\end{array}$ \\
& $\begin{array}{l}\text {-Significantly reduces volume } \\
\text {-Some of the heat created can be } \\
\text { recycled. }\end{array}$ & $\begin{array}{l}\text {-The ash to be disposed of after the incineration process } \\
\text {-The nutrients are wasted. }\end{array}$ \\
\hline
\end{tabular}

Source: The Animal By-product Regulation, 2003.

\subsection{Effects of Abattoir Effluents on Water Quality}

It has been reported that waste can affect water, land or air quantities; if proper practices of management are not followed (Ogboru, 2001). Animal waste can be valuable for crops but can cause water quality impairment. It also contains organic solid, trace heavy metals, salts, bacteria, viruses, other micro-organism, and sediment. The waste from animals can also be washed into the stream if unprotected and reduces oxygen; thereby endangering aquatic life. Amole (2008) also reported that improper animal waste disposal can lead to animal disease being transmitted to human through contact with animal faeces. Magaji (2009) reported that abattoir effluent reaching streams contributed a significant level of nitrogen, phosphorous and oxygen demand and other nutrient resulting in steam pollution. Chukwu (2008) attributed excessive nitrate in Minna ground waters to concentrated livestock manure usage. The wells in the meat processing area sometimes result in being polluted. Wells in the vicinity of abattoir which serves as a source of water to abattoir constitute a high risk for the butchers and users of the wells (Magaji, 2009).

Medical experts reported in 2011 that abattoir activities cause diseases, which include; pneumonia, diarrhea, Typhoid fever, Asthma, Wool Sorter disease, respiratory and chest disease. E. coli infection source was reported to be undercooked beef which has been contaminated; often in an abattoir with faces containing the bacterium. These diseases can spread from the abattoir to the neighborhood via vectors animals. However, a growing population with an increase in demand for meat has resulted in increased abattoir related pollution and has attracted intervention in many developed countries (Magaji, 2009). There is a high level of awareness on pollution from animals and over the years several measures have been put in place to protect the public health and the environment. According to Adelegan (2002), the European Commission introduced a pan - European fresh meat directives signed to standardize structures in the United Kingdom. On the contrary, little intervention or response had been made in the developing nations. The pollution load on a water body from abattoir effluent can be quiet high. For example, studies done in Canada and Nigeria showed very high contaminant level in abattoir effluent (Magaji, 2009). Most of these are known to be hazardous to human beings and aquatic life. Likewise, improper disposal of effluent from slaughterhouse could lead to the transmission of pathogens to humans and cause disease such as Bacillus, salmonella infection, Brucellosis, and helminths disease and infections (Okecha, 2000). Philip, 2004 reported that in developed countries an estimated 80\% of all diseases and over one-third of deaths are caused by consuming contaminated water. This work is to investigate the bacteriological, physiochemical characteristics and various toxic elements of Abattoir waste, as affected underground water sources in the surrounding houses near the abattoir (Magaji, 2009).

\subsection{Some Ground Water Quality Indicators}

\section{- Physical}

These include colours, odours, taste, temperature, turbidity, etc. 


\section{- Chemical}

Aluminum, Arsenic, barium, cadmium, chloride, chromium, conductivity, copper, cyanide, fluoride, hardness, hydrogen sulphate, iron, lead, magnesium, manganese, mercury, nickel, nitrate, nitrite, $\mathrm{pH}$, sodium, sulphate, total dissolved solids, zinc, etc.

\section{- Biological}

Detergent, mineral oil, pesticides, polyaromatic hydrocarbons, total organic carbon and phenols amongst others Table 2Physical Parameters

\begin{tabular}{|l|l|l|l|l|}
\hline \multicolumn{1}{|c|}{ Parameter } & \multicolumn{1}{c|}{ Unit } & \multicolumn{1}{c|}{$\begin{array}{c}\text { The maximum permitted } \\
\text { levels (WHO) }\end{array}$} & Health Impact & Note \\
\hline Colour & TCU & 15 & None & \\
\hline Odour & - & Unobjectionable & None & \\
\hline Taste & - & Unobjectionable & None & \\
\hline Temperature & O Celsius & Ambient & None & \\
\hline Turbidity & NTU & 5 & None & \\
\hline
\end{tabular}

Table 3 Chemical Parameters

\begin{tabular}{|c|c|c|c|c|}
\hline Parameter & Unit & $\begin{array}{l}\text { The maximum } \\
\text { permitted levels } \\
\text { (WHO) }\end{array}$ & Health Impact & Note \\
\hline Aluminium (Al) & $\mathrm{Mg} / \mathrm{L}$ & 0.2 & $\begin{array}{lll}\begin{array}{l}\text { Potential } \\
\text { disorder }\end{array} & \text { neuron } & \text { degenerative } \\
\end{array}$ & Note 1 \\
\hline Arsenic (As) & $\mathrm{Mg} / \mathrm{L}$ & 0.01 & Cancer & \\
\hline Barium & $\mathrm{Mg} / \mathrm{L}$ & 0.7 & Hypertension & \\
\hline Cadmium $(\mathrm{Cd})$ & $\mathrm{Mg} / \mathrm{L}$ & 0.003 & Toxic to the kidney & \\
\hline Chloride $(\mathrm{Cl})$ & $\mathrm{Mg} / \mathrm{L}$ & 250 & None & \\
\hline Chromium (Cr6+) & $\mathrm{Mg} / \mathrm{L}$ & 0.05 & Cancer & \\
\hline Conductivity & $\mathrm{Us} / \mathrm{cm}$ & 1000 & None & \\
\hline Copper $(\mathrm{Cu}+2)$ & $\mathrm{Mg} / \mathrm{l}$ & 1 & Gastrointestinal disorder & \\
\hline Cyanide (CN-) & $\mathrm{Mg} / \mathrm{l}$ & 0.01 & $\begin{array}{l}\text { Toxic to the thyroid and nervous } \\
\text { system }\end{array}$ & \\
\hline Floride (F-) & $\mathrm{Mg} / \mathrm{l}$ & 1.5 & $\begin{array}{l}\text { Fluorosis skeletal tissue (bone and } \\
\text { teeth) morbidity }\end{array}$ & \\
\hline Hardness (as CaCO3) & $\mathrm{Mg} / 1$ & 150 & None & \\
\hline $\begin{array}{ll}\text { Hydrogen } & \text { Sulphide } \\
(\mathrm{H} 2 \mathrm{~S}) & \end{array}$ & $\mathrm{Mg} / \mathrm{l}$ & 0.05 & None & \\
\hline Iron $(\mathrm{Fe}+2)$ & $\mathrm{Mg} / \mathrm{l}$ & 0.3 & None & \\
\hline Lead $(\mathrm{Pb})$ & $\mathrm{Mg} / \mathrm{l}$ & 0.01 & $\begin{array}{l}\text { Cancer, interference with Vitamin } \\
\mathrm{D} \text { metabolism, affects mental } \\
\text { development in infants, toxic to } \\
\text { central and peripheral nervous } \\
\text { systems. }\end{array}$ & $\begin{array}{l}\text { Magnesium } \\
(\mathrm{mg}+2)\end{array}$ \\
\hline Magnesium (mg+2) & $\mathrm{Mg} / \mathrm{l}$ & 0.20 & Consumer acceptability & \\
\hline Manganese $(\mathrm{Mn}+2)$ & $\mathrm{Mg} / \mathrm{l}$ & 0.2 & Neurological disorder & \\
\hline Mercury $(\mathrm{Hg})$ & $\mathrm{Mg} / \mathrm{l}$ & 0.001 & $\begin{array}{l}\text { Affects the kidney and the central } \\
\text { nervous system }\end{array}$ & \\
\hline Nitrate (NO3) & $\mathrm{Mg} / \mathrm{l}$ & 0.02 & $\begin{array}{l}\text { Cyanosis and asphyxia in infants } \\
\text { under three months }\end{array}$ & \\
\hline Nitrite (NO3) & $\mathrm{Mg} / \mathrm{l}$ & 50 & $\begin{array}{l}\text { Cyanosis and asphyxia in infants } \\
\text { under three months. }\end{array}$ & \\
\hline $\mathrm{PH}$ & $\mathrm{Mg} / \mathrm{l}$ & $6.5-8.5$ & None & \\
\hline Sodium(Na) & $\mathrm{Mg} / 1$ & 200 & None & \\
\hline Sulphate(SO4) & $\mathrm{Mg} / \mathrm{l}$ & 100 & None & \\
\hline Total dissolved solids & $\mathrm{Mg} / \mathrm{l}$ & 500 & None & \\
\hline $\operatorname{Zinc}(\mathrm{Zn})$ & $\mathrm{Mg} / \mathrm{l}$ & 3 & None & \\
\hline
\end{tabular}


Table 4 Organic Constituent

\begin{tabular}{|l|l|l|l|l|}
\hline Parameter & Unit & Maximum Permitted Level (WHO) & Health Impact & Note \\
\hline Detergent & $\mathrm{Mg} / 1$ & 0.01 & Possible carcinogenic & \\
\hline Mineral oil & $\mathrm{Mg} / \mathrm{l}$ & 0.003 & Possible carcinogenic & \\
\hline Pesticides & $\mathrm{Mg} / \mathrm{l}$ & 0.01 & Possible carcinogenic & \\
\hline Phenols & $\mathrm{Mg} / \mathrm{l}$ & 0.001 & Possible carcinogenic & \\
\hline Poly Aromatic Hydrocarbons & $\mathrm{Mg} / \mathrm{l}$ & 0.007 & Possible carcinogenic & \\
\hline Total organic carbon & $\mathrm{Mg} / 1$ & 5 & Cancer & \\
\hline
\end{tabular}

\section{MATERIALS AND METHODS}

The study adopts a combination of qualitative and quantitative methodology, including laboratory testing and sample analyses gotten from field. Water quality depends on the Bio-physicochemical composition of the water.The data was collected from both primary and secondary sources, but most of the information was obtained from the primary source. The primary source of data includes reconnaissance survey, field observation and the water sample analysis that was carried out in a standard laboratory. The secondary source of data includes the vital information that where got from urban planning, journals, seminar paper, textbooks and the internet.

\subsection{Methods of Data Collection}

A total of three sampling points were selected, two from the abattoir and one outside the abattoir and they are described as follows;

(a) Well $9.76 \mathrm{~m}$ away from the abattoir effluent dump well

(b) Borehole $16.80 \mathrm{~m}$ from the abattoir effluent dump well

(c) Control site $40 \mathrm{~m}$ away from the abattoir.

\subsection{Reconnaissance Survey and Field Observation}

Reconnaissance survey was carried out to familiarize the researcher with the various environmental characteristics of the study area. During this process, some vital information were obtained and this formed a foundational knowledge that helped to enhance the planning and costing as well as preparation of materials needed for the study. This was also done to get information regarding the kinds of animals kept and slaughtered in the abattoir, get a comprehensive knowledge on how the animals are being slaughtered, also know the existing waste management practices and source of water in the abattoir.

\subsection{Water Sample Collection}

Water samples were collected with three containers; one from the well in the abattoir, another from the borehole in the abattoir and the last one was collected from a well forty metres away from the abattoir so as to ascertain if the abattoir effluents contaminates the groundwater or not, the containers were properly washed before going to the sampling point and each container was finally washed with the water from the wells and borehole in the sampling point. The water samples were collected between 6:00am and 6:30 when the water had settled; the water samples was collected before the arrival of anyone in the sampling point because continuous fetching of water from the wells and the borehole can cause the water to change colour and become muddy. After collecting the water samples, the containers were covered and labelled as "well", "borehole" and "control". They were stored coolers and then transported to the laboratories for analysis.

\subsection{Laboratory Analysis of Water Samples}

The laboratory analysis of the water samples were carried out at the Kaduna State Water Board in Barnawa, Kaduna state. The water samples were tested for selected physical, chemical and biological parameters such as Total Dissolved Solids, Total Suspended Solid, Biological Oxygen Demanded, pH, nitrate, turbidity and total coliform. The laboratory analyses were carried out using standard analytical methods and procedures for water quality analysis.

\subsection{Methods of Data Analysis}

The data that were collected from the laboratory analysis of the water samples were further analysed using different statistical tools. These include mean and standard deviation. The Analysis of variance was also used to determine the variation in the concentration of the parameters of water samples collected from well, borehole and control sites. The use of ANOVA tests the hypothesis which was earlier stated. The results obtained were presented in tables and graphs. 


\section{RESULTS AND DISCUSSION}

6.1 Disposal of the Wastes Generated From Gwagwalada Abattoir

Ways in which waste are disposed off in Gwagwalada abattoir;

\section{- $\quad$ Solid Waste}

Different types of solid waste are generated from Gwagwalada abattoir and their methods of disposal are different depending on the type of solid waste generated at that time. Most of the wastes from this abattoir serve as a raw material to some manufacturing industries and firms. Leather processing industries come to buy some of the hides for the production of belt, shoes, and bags, while some of these hides are sold to other people who roast the hides, wash and use them as "Kpomo". The bones, horns, and hooves are sold out to manufacturing company who use them as raw material to produce ceramics. The rumen heaped outside and all the animal dungs from the lairage are sold to farmers who use them to improve soil fertility and their crop yield.

Liquid Waste

All the liquid wastes in Gwagwalada abattoir are connected through one channel to empty itself in a very large pit called "Rijiya" when the pit is filled, it will be carried away by a certain machine that is designed for that purpose.

\section{Gaseous Waste}

Disposal of gaseous wastes in Gwagwalada abattoir is still a very big problem the butcher men are really facing because it pollutes the abattoir environment and its vicinity. Most abattoirs in Nigeria make use of coal, firewood and gas flames to burn hides so as to reduce the risk of polluting the environment with heavy smoke but the abattoir in Gwagwalada still makes use of tires, plastic and rubber to burn hides and this has been a very big problem to them especially the odours that come from the lairage, the heaped rumen and the ones that come from the liquid wastes in the pit called "Rijiya" which they don't know how to control.

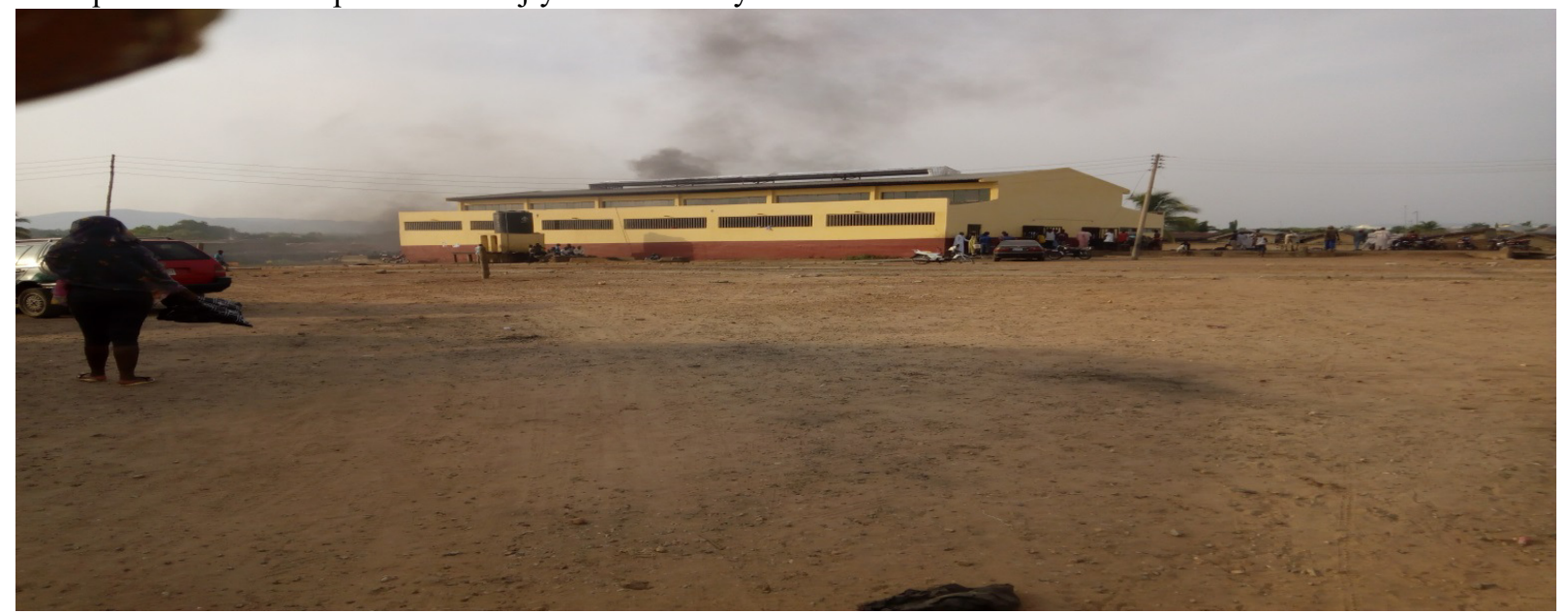

Plate1: Gwagwalada Abattoir, FCT-Abuja

Source; Author's field survey, 2018

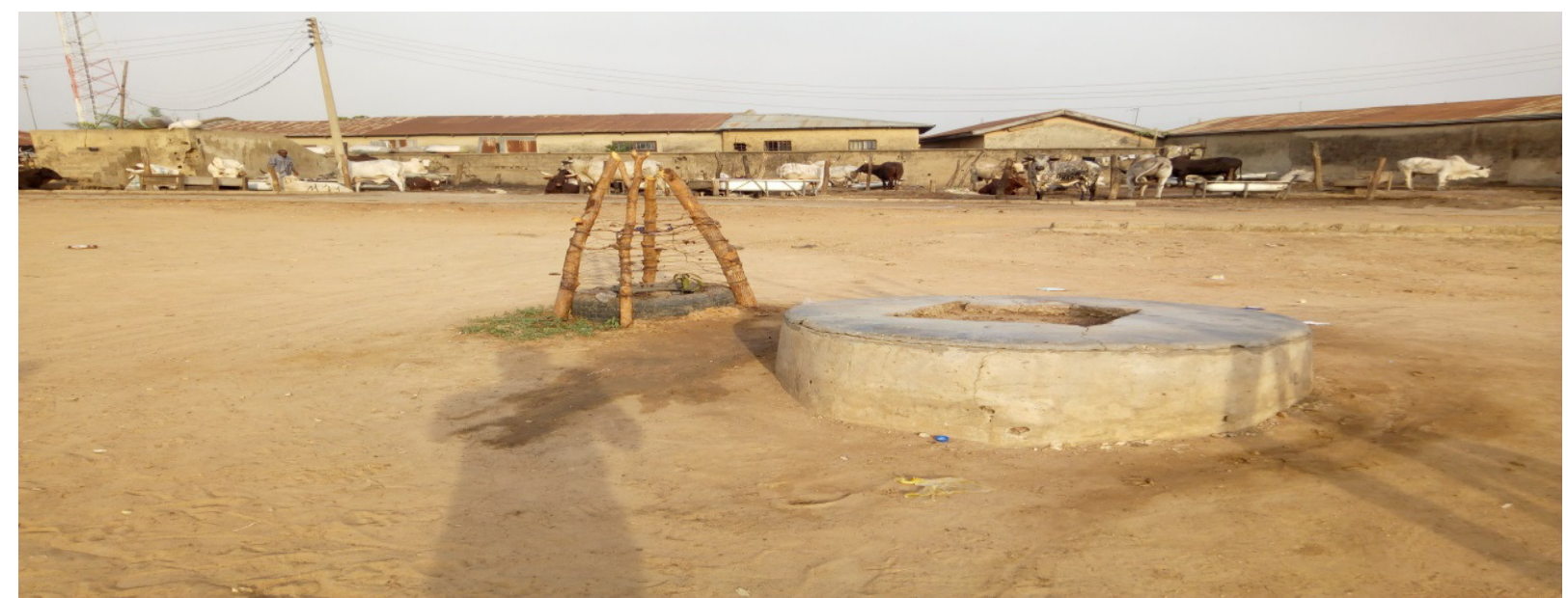

Plate2: Effluent well at Gwagwalada Abattoir, FCT-Abuja

Source; Author's field survey, 2018 


\subsection{Variation in the Concentration of Parameters in Ground Water Samples}

Below is a table showing the result of the analysis of the variation in the concentration of parameters of groundwater samples.

The table 5 concentration of parameters of groundwater samples in the study area

\begin{tabular}{|l|l|l|l|l|}
\hline Parameters & Borehole & Well & Control Sample & WHO Guidelines \\
\hline TDS (mg/l) & 54.15 & 84.73 & 28.02 & 1000 \\
\hline TSS (mg/l) & 0.81 & 8.00 & 0.01 & N.M \\
\hline BOD(mg/l) & 0.90 & 7.08 & 0.90 & 10 \\
\hline pH & 6.70 & 5.50 & 6.50 & $6.5-8$ \\
\hline Nitrate(mg/l) & 1.06 & 22.78 & 0.01 & 10 \\
\hline Turbidity(NTU) & 3.69 & 18.10 & 0.00 & N.M \\
\hline Total Coliform $(\mathrm{cfu} / 100 \mathrm{ml})$ & 27.43 & 63.62 & 0.27 & 10 \\
\hline
\end{tabular}

6.2.1 The variation in Concentration of each parameter from the well to the borehole to the controlled point.

\section{Total Dissolved Solid}

The Total Dissolved Solid concentration is the sum of cations and anions in the water. Therefore, the Total Dissolved Solid test provides a qualitative measure of the number of dissolved ions in the water. The analysis carried out on these water test shows that the concentration of the Total Dissolved Solids in the well is higher than that of the borehole and the control site but the borehole concentration is also higher than the control site.

\section{- $\quad$ Total Suspended Solid}

Total Suspended Solids is solid materials including organic materials and inorganic materials that are suspended in water. These materials include silt, plankton, and industrial wastes. The above result has shown that all the samples have some contentment of suspended solids in them but it is higher in the well followed by the borehole and then the control site.

\section{- $\quad$ Biological Oxygen Demanded}

Biological Oxygen Demand is a measurement of the amount of dissolved oxygen that is used aerobic microorganisms when decomposing organic matter in water. The biological oxygen demand is higher in the well than the borehole and the control site, but the result shows that the borehole and the control site have the same amount of biological oxygen demanded.

- $p H$

The $\mathrm{pH}$ means the potential of hydrogen and it is a numeric scale used to specify the acidity or alkalinity of water-soluble substances. A pH value is numbered $1-14$, with 7 as the neutral point, values below 7 indicates acidity which increases as the number decreases, 1 being the most acidic. Values above 7 indicate alkalinity which increases as the number increases, 14 being the most alkaline. The result shows that the $\mathrm{pH}$ of the three water sample has some percentage of acidity in them but the well is higher than the borehole and the control site.

\section{- $\quad$ Nitrate}

Nitrate is a polyatomic ion and it is a problem as a contaminant in drinking water (primarily from wells and boreholes) due to its harmful biological effects. High concentrations of nitrate can cause methemoglobinemia and have been cited as a risk factor in developing gastric intestinal cancer. The result of this analysis shows that the well has the highest concentration of nitrate followed by the borehole then the control site; this has shown that the well water is not good for drinking.

\section{- $\quad$ Turbidity}

Turbidity is the cloudiness or haziness of a fluid caused by large numbers of particles that are generally invisible to the naked eyes. The measurement of turbidity is a key test of water quality. In open water like wells streams and rivers, it is caused by the growth of phytoplankton and human activities that disturbs the land such as mining, construction, and agricultural activities can lead to high sediment levels entering water bodies during rainy season due to runoff. The result shows that the effects of turbidity were high in the well because it is opened water, little in the borehole and was not found in the control site.

\section{- $\quad$ Total coliform}

Coliforms are a broad class of bacteria found in our environment (land and water) including the faces of a man and other warm-blooded animals. The presence of coliform bacteria in drinking water may indicate a possible presence of harmful, harmful disease-causing organism. Drinking water must be free of disease-causing organisms called pathogens. The result shows that the amount of bacteria in the well is greater than borehole and the control site, this means that the well has a high amount of bacteria than the borehole and the control site.

\subsubsection{Variation in Concentration of the Parameters between the Well Water and WHO Standard.}

- $\quad$ Total dissolved solids

The total Dissolved Solids in the well water is not at variance with the World Health Organization standard for drinking water quality because the WHO standard ranges from $0 \mathrm{mg} / \mathrm{l}-1000 \mathrm{mg} / \mathrm{l}$ and the result got from the analysis of the well water shows that the Total Dissolved Solids in the well water is $84.73 \mathrm{mg} / \mathrm{l}$. 
- $\quad$ Total suspended solids

The result obtained from the analysis shows that the total suspended solids in the well water is $8.00 \mathrm{mg} / 1 \mathrm{while}$ the World Health Organization standard for drinking water quality was not stated.

- Biological oxygen demanded

The result obtained from the analysis shows that the Biological Oxygen Demanded in the well water was in line with the world health organization standard for drinking water quality since the well water is $7.08 \mathrm{mg} / 1$ while the WHO is $10 \mathrm{mg} / \mathrm{l}$.

- $p H$

The $\mathrm{pH}$ of the well water is 5.50 and the WHO standard ranges from 5.00 to 8.00 . This means that the $\mathrm{pH}$ for the well water is in line with the world health organization standard for drinking water quality.

- $\quad$ Nitrate

The percentage of nitrate in the well water is at variance with the WHO standard because the world health organization standard for drinking water quality ranges from $0 \mathrm{mg} / \mathrm{l}-10 \mathrm{mg} / \mathrm{l}$ but the nitrate in the well water is $22.78 \mathrm{mg} / 1$

- $\quad$ Turbidity

The result obtained from the analysis shows that the content of turbidity found in the well water is 18.10 NTU, while the world health organization standard for drinking water quality was not stated.

\section{- Total coliform}

The total coliform for the world health organization standard ranges from $0 \mathrm{cfu} / \mathrm{ml}$ to $10 \mathrm{cfu} / \mathrm{ml}$ while the one found in the well water is $63.62 \mathrm{cfu} / \mathrm{ml}$. this means that the coliform in the well water is at variance with the WHO standard.

6.2.3 Variation in Concentration of the Parameters between the borehole water and WHO standard for drinking water quality.

- Total dissolved solids

The Total Dissolved Solids in the borehole water is not at variance with the world health organization standard for drinking water quality because the WHO standard ranges from $0 \mathrm{mg} / \mathrm{l}-1000 \mathrm{mg} / \mathrm{l}$ and the result got from the analysis of the borehole water shows that the Total Dissolved Solids in the well water is 54.15mg/l.

- $\quad$ Total suspended solids

The result obtained from the analysis shows that the Total Suspended Solids in the borehole water is $0.81 \mathrm{mg} / 1$ while the World Health Organization standard for drinking water quality was not stated.

- Biological oxygen demanded

The result obtained from the analysis shows that the Biological Oxygen Demanded in the borehole water was in line with the World Health Organization standard for drinking water quality since the borehole water is $0.90 \mathrm{mg} / 1$ while the WHO ranges from $0 \mathrm{mg} / 1$ to $10 \mathrm{mg} / \mathrm{l}$.

- $p H$

The $\mathrm{pH}$ of the borehole water is 6.70 and the WHO standard for drinking water ranges from 5.00 to 8.00 . this means that the $\mathrm{pH}$ for the well water is in line with the World Health Organization standard for drinking water quality.

\section{- $\quad$ Nitrate}

The percentage of nitrate in the borehole water is at variance with the WHO standard because the World Health Organization standard for drinking water quality ranges from $0 \mathrm{mg} / 1-10 \mathrm{mg} / \mathrm{l}$ but the nitrate in the borehole water is $1.06 \mathrm{mg} / \mathrm{l}$

\section{- $\quad$ Turbidity}

The result obtained from the analysis shows that the content of turbidity found in the borehole water is 3.69 NTU, while the World Health Organization standard for drinking water quality was not stated.

\section{- Total coliform}

The total coliform for the World Health Organization standard ranges from $0 \mathrm{cfu} / \mathrm{ml}$ to $10 \mathrm{cfu} / \mathrm{ml}$ while the one found in the borehole water is $27.43 \mathrm{cfu} / \mathrm{ml}$. This means that the coliform in the borehole water is at variance with the WHO standard 
Table 6Analysis of Variance for the Variation of concentration of Parameters between well, borehole and WHO standard

\begin{tabular}{|c|c|c|c|c|c|c|c|c|}
\hline & & & & Sum of Squares & $\mathrm{df}$ & Mean Square & $\mathrm{F}$ & Sig. \\
\hline \multirow[t]{5}{*}{ BOREHOLE } & \multirow[t]{3}{*}{ Between Groups } & \multicolumn{2}{|l|}{ (Combined) } & 1992.923 & 3 & 664.308 & 4.235 & .133 \\
\hline & & \multirow[t]{2}{*}{ Linear Term } & Weighted & 1932.928 & 1 & 1932.928 & 12.323 & .039 \\
\hline & & & Deviation & 59.995 & 2 & 29.998 & .191 & .835 \\
\hline & \multicolumn{3}{|l|}{ Within Groups } & 470.562 & 3 & 156.854 & & \\
\hline & \multicolumn{3}{|l|}{ Total } & 2463.485 & 6 & & & \\
\hline \multirow[t]{5}{*}{ WELL } & \multirow[t]{3}{*}{ Between Groups } & \multicolumn{2}{|l|}{ (Combined) } & 4174.260 & 3 & 1391.420 & 2.379 & .248 \\
\hline & & Linear Term & Weighted & 3521.593 & 1 & 3521.593 & 6.021 & .091 \\
\hline & & & Deviation & 652.666 & 2 & 326.333 & .558 & .622 \\
\hline & \multicolumn{3}{|l|}{ Within Groups } & 1754.727 & 3 & 584.909 & & \\
\hline & \multicolumn{3}{|l|}{ Total } & 5928.987 & 6 & & & \\
\hline
\end{tabular}

\subsection{Hypothesis Verification}

The result of the statistical analysis using ANOVA above shows that there is no significant difference for all the parameters except for Suspended Solid, turbidity that was not mentioned and total coliform that was at variance with the WHO standard. This difference could be attributed to the abattoir effluents leachates to the groundwater. Ho: There is no significant variation in the concentration of the parameters between the well water sample, the borehole samples and the World Health Organization standard for drinking water.

Hi: There is significant variation in the concentration of the parameters between the well water sample, the borehole samples and the World Health Organization standard for drinking water.

The null hypothesis is rejected since the calculated value is greater than the table value and it has been observed that in table 2 the result of the analysis is at variance with the World Health Organisation standard for drinking water quality. Some are below the standard while some are above the standard.

\subsubsection{The implication of the result compared with other standards}

The maximum permissible limit and possible health implications of the parameters, referring to the tables above and other allowable limits of FEPA, FAO, and WHO, we will examine the parameters from our findings, variation from these standards and their implication.

Total dissolved solid and suspended solid

The result obtained close to FEPA (1991) limits of $200 \mathrm{Mgl}^{-1}$ and far below WHO tolerance limit of $500 \mathrm{Mgl}^{-1}$. Suspended solid exceed allowable limit of FEPA which is $30 \mathrm{Mgl}^{-1}$. This is likely related to the presence of organic matter and mainly the fact that abattoir does not treat its waste at all. This indicates a high potential to cause gross organic pollution.

Biochemical Oxygen demand

This shows the measure of pollution present in the water obtained by measuring the amount of oxygen absorbed from the water by micro-organisms present in it. Results obtained are within allowable limits of $40 \mathrm{Mgl}^{-1}$ for FEPA and $20 \mathrm{Mgl}^{-1}$ for FAO for water used for agricultural purposes. The values are at variance with WHO (2004) permissible limits of $0.30 \mathrm{Mgl}^{-1}$ for drinking water which implies that is very dangerous to drink untreated water.

Nitrate

The result of all the analysis is on the high side above FEPA and WHO limit of $10 \mathrm{Mgl}^{-1}$. Excess nitrate in water could lead to cyanosis and asphyxia (a blue baby syndrome in infants under three months). Excess nitrate in water use for irrigation causes lodging of plants, delay in ripening and increases the susceptibility of plants to pests and diseases, it can also lead to less yield if applied on soil

Turbidity

The turbidity values are far above WHO (2004) and FEPA limit of 5FTU and 10 FTU respectively. The result of the abattoir effluents shows that it has great potentials to be deleterious.

Total Coliform

This is also above the WHO of $0 \mathrm{Mgl}^{-1}$ with health possible implication of urinary tract infection, bacteremia, meningitis, diarrhea (one of the main of morbidity and mortality among children) and acute renal failure.

\section{SUMMARY AND CONCLUSION}

The research revealed that groundwater poses an environmental risk and health risk to the users if not treated as the parameters examined shows the lowering of the water quality and making the groundwater unhealthy for drinking and other uses. The study also shows that there is no treatment plant for the abattoir effluents. The regulations for abattoir sanitation are not enforced and the people who live around the abattoir are not aware of 
the grave implication of abattoir effluents on groundwater which the evidence was shown in the research work as the result were at variance with the World Health Organisation standard.

\section{RECOMMENDATIONS}

The following recommendations were provided for the study;

i. For the fact that there is always precipitation, the abattoir effluent leaches downward, so the groundwater capacity to assimilate pollution will be very high. There should be an urgent need for the enforcement of the regulation for abattoir sanitation in Gwagwalada.

ii. There should be regular check-in other to monitor the quality of the groundwater in the study area to minimize health risk as well as the environmental risk in Gwagwalada

iii. There should be an urgent need for a treatment plant for the abattoir effluents and other abattoir waste.

iv. There is a need for a clearly established and coordinated policy framework to tackle the liquid waste from the abattoir and water pollution in Gwagwalada.

v. From the findings of the research work, it is much better to sink boreholes instead of wells in Gwagwalada.

vi. The people who leave around the study area should at least make use of chlorine for the treatment of water before use to reduce the health risk.

vii. This study did not exhaust the list of the parameters that could impair groundwater such ones can also be investigated.

viii. Further research work should be done on the Assessment of the effects of abattoir effluents on the surface water quality and on crop quality within the study area. The extent to which the groundwater has affected the users could be studied as well.

\section{Acknowledgment}

The authors wish to acknowledge the Staff and medical personnel working in Gwagwalada abattoir for granting permission during data collection as well as everyone who contributed to this research.

\section{REFERENCES}

Abattoir acts 1988 from; http//www.irishstatutebookie/1988/actpub/ 0008/index.html

Adelegan J.A (2002); Environment policy and slaughter house waste in Nigeria procedure of the $28^{\text {th }}$ WEDC conference, calculta, India pp 3-6.

Alonge, D.O (1991); Textbook of meat hygiene in tropics farmcoe press, Ibadan SSPP

American public health association (APHA), 2000; system for analysis waste water Hach Company (WHO and APHA) hand book of Dr. 2000 spectrophotometer.

Bello, Y.O and Oyedemi D.T.A (2009); the impact of abattoir activities and management in residential neighbourhood: In Ogbomoso Nigeria, Civil and Environmental Research www.iiste.org ISSN 22245790(Paper) ISSN 2225-0514 (Online) Vol.7, No.9, 2015

Best Management Practices for Large Animal Carcass Composting, June 2009 (Maine Department of Agriculture, Food and Rural Resources), journal of ecology and natural environment vol.1(6),32-36

Bulletin of the world health organization, 2000 contamination of drinking water by asence in Bangladesh: A public health emergency bulletin of world health organization vol 78 No.9 genbra 2000.

Chukwu O, H.I Mustapha and H.B Abdul Gafar (2008); the effect of Minna abattoir wastes on surface water quality, Environmental research journal 2(6): 334-338, Med well online.

Balogun .A. (2001), "The position and influence of the Gwagwalada Area Council" University of Lagos press, pp. $35-42$

Ejaro S.P (2013). "Land accessibility problem in Nigeria: A case study of Gwagwalada, Research journal of social science and management, volume II, page 160-162.

Federal Environmental protection Agency (FCPA) 1991; National interim guidelines and standard for industrial effluents, gaseous emission and hazardous wastes, Abuja Nigeria, pp 33-63

Foster Robert (2005); meat packing industry: Microsoft Encarta encyclopaedia Standard. African journal of biomedical research pp12 (1), 31-35

Kelvin G. Kenneth M. Strezepek (2000); A method of rapid ground water quality assessment in developing countries, a case study of China yellow River. Journal of the Royal Institute of Public Health, 12(6), $152-$ 154.

Maduka H.C.C (2005); water pollution and man's health, The internet journal of gastroenterology:4 (1).

Magaji J.Y (2009); The impact of waste dump on soil and water quality at Dump site Mpape, Abuja.PhD, Thesis progress report, Department of Geography and Environmental Management.

Meadows, R (1995); ' 'Livestock legacy' Environmental health prospective 103 (12) 1096, 1100

Ogboru, J.O (2001); ' 'Environmental pollution and Disease Susceptibility: An analytical study of shallow well water in Ondo town, Benin journal of Environmental Education Vol. 1 No.1, pg 33 - 42. 
Okecha S.A (2000); Pollution and conservation of Nigeria Environment, Journal of T Africa international associates, Owerri, Nigeria

Omole D.O; Longe E.O (2008); An assessment of impact of abattoir effluent on river Illo, Ota, Nigeria, Journal of environmental science and technologyVol. 1. Issues 2 pg 56-64.

Osibanjo O, and G. U. Aide (2007); Impact of effluent from Bodija Abattoir on the physicochemical parameters of Oshenkaye stream in Ibadan city, Nigeria afr. J. biotech, 6(15): 1806-1811.

Tebutt, T.H.Y (1983); Relationship between National water Quality ad Health, UNIESCO Publication

Turk, J (1980); Introduction to environmental studies, W. B. S. Company Philadelphia

U.S Environmental Protection Agency Office of Water regulations and Standards, Monitoring and Data support Division 1980 September. Technical guidance manual for performing waste load allocations, Simplified analytical method for determining NPDES effluents limitation for POTWS discharging into low flow streams Washington, DC, Government printing office

UNESCO (2006); Water shared responsibility. The United Nations control water development report 2, New York 801. At: http//unescounesco.Org/waterimages/00/45/ 24540SE.Pdf.

WHO/UNICEF (2005); Water for life, making it happen: a decade for action 2005-2015.Geneva44at $\mathrm{http} / / \mathrm{www}$.who.in/watersanitationhealth/water for life

World Health Organization (2004); Guidelines for drinking water quality, W.H.O. Geneva

World Health Organization (1997); Basic Environmental Health, WHO, Geneva Switzerland $2^{\text {nd }}$ edition 3

World Health Organization (1982); Rapid assessments of sources of air, water,and land pollution (WHO offsets publication no. 62 Geneva, Switzerland. World Health Organization (2001); 'Global water supply and sanitation assessment 2000 report' Geneva, World Health Organization.nd henalytic anaemia 